\title{
LA NOTICIA DE LA MUERTE DE POLICISNE DE BOECIA: EXPRESIONES DE DOLOR EN UN LIBRO INCONCLUSO ${ }^{1}$
}

\author{
LuCILA LOBATO OSORIO \\ Universidad Nacional Autónoma de México \\ lucilalobato@gmail.com
}

$\mathrm{E}$ 1 Policisne de Boecia (Valladolid, 1602) es uno de los libros de caballerías más mencionados en los recuentos del género castellano del siglo XVI, ya que es el último de su tipo impreso antes del Quijote. Con todo, esta obra de Juan de Silva y de Toledo tuvo poca suerte editorial, lo cual se ha reflejado en la escasa atención que ha recibido de la crítica especializada. Quizá por su carácter epigonal (Sales Dasí 2008), por no pertenecer a un llamativo ciclo o por la ingente cantidad de textos por analizar, del Policisne de Boecia se sabe poco (Russell 1982; Sales Dasí 2009 y 2010). Sin embargo, esta obra presenta algunos elementos llamativos de la literatura caballeresca, que tan perdurable ha resultado. Este artículo se centrará en analizar las expresiones de dolor surgidas por la noticia de la supuesta muerte de Policisne a fin de identificar los mecanismos estilísticos con los que el autor intenta conmover al lector, exaltar al caballero y generar expectativas sobre la segunda parte del libro; la cual, como sabemos, nunca vio la luz.

Como integrante del género caballeresco, el Policisne de Boecia incluye los elementos constitutivos de este: estructura basada en aventuras de los personajes habituales, con lances bélicos, escenas de amor y cortesía, que se sitúan en ambientes de magia donde las resoluciones pueden producirse por medio de prodigios maravillosos o milagros. Desde luego, la obra no deja de tener su dosis

\footnotetext{
Agradezco a Emilio Sales Dasí por su apoyo para la realización de este trabajo, mismo que se hizo en el marco del proyecto PAPIIT (núm. IN403614), «Teoría y análisis de los textos breves en la literatura caballeresca hispánica» de la Dirección General de Asuntos del Personal Académico y de la Facultad de Filosofía y Letras de la Universidad Nacional Autónoma de México.
}

Edad de Oro, XXXIV (2015), pp. 115-130, ISSN: 0212-0429 - DOI http://dx.doi.org/10.15366/edadoro2015.34.007 
de originalidad y sus peculiaridades ${ }^{2}$, entre las que destacan la caracterización y tratamiento de algunos personajes ${ }^{3}$. Es el caso del caballero protagonista, el cual aparece relativamente poco en la obra. Su aparición es tardía (cap. 14), luego de un largo periplo de sus padres para concebirlo; su investidura caballeresca es retardada por las aventuras de otros personajes de la corte de Boecia y, justo cuando empieza a brillar con sus hazañas iniciales y está de camino a la aventura que podría consagrarlo y completarlo en el plano amoroso (cap. 80), queda malherido y en manos de la hija de su enemiga; entonces, el autor frena sus acciones hasta una prometida segunda parte del libro.

Los episodios que siguen a esta «desaparición» del protagonista tratan del dolor de la corte de Boecia al enterarse de su supuesta muerte ${ }^{4}$. Por lo cual, quedan

2 Emilio Sales Dasí sostiene que «la creatividad de Juan de Silva y de Toledo no pudo rivalizar con la de otros autores como Rodríguez de Montalvo, Feliciano de Silva u Ortúñez de Calahorra. Pero donde este escritor no descuella por su original inventiva, su trabajo permite retener con total nitidez la funcionalidad de unos moldes ficcionales que ejemplifican la doble tensión latente en el género: conservadurismo, en tanto que respeto y aprovechamiento de los modelos sancionados por la aprobación del público, y constante evolución en busca de nuevos registros que enriquezcan los paradigmas iniciales. Esta dialéctica puede advertirse a lo largo de los noventa y seis capítulos de la obra» (2009: 268).

3 En su análisis sobre la malvada Caruça, Sales Dasí destaca, precisamente, su originalidad a partir de la complejidad de sus rasgos: «sus facetas diversas la pluralizan y enriquecen su retrato, siendo algo así como una síntesis de otros modelos precedentes fácilmente reconocibles. [...] Confluyen en Caruça aspectos consustanciales al tipo de la maga hostil, de la mujer libidinosa o de la dama cruel y vengativa» (2009: 277).

4 El motivo de la muerte aparente ha sido revisado desde la perspectiva de un personaje que parece que muere, pero por diversas razones regresa a la vida. Este motivo podría rastrearse hasta la novela griega de la Antigüedad Tardía, donde se trata o de un fingimiento o de una confusión; también ha perdurado en el ámbito folclórico. Cuesta Torre (1999) lo analizó en la literatura artúrica y, en particular, en el Libro de Apolonio. Por su parte, Campos García-Rojas (2009) revisó los diferentes tipos de muertes y regresos maravillosos a la vida de los caballeros en el género castellano.

La variación de este motivo es relativamente frecuente. Es el caso de hacer el énfasis en la noticia, siempre falsa, de que el caballero protagonista ha muerto y donde el interés narrativo está puesto - más que en el trance de la muerte de los personajes y su aceptación, para luego percatarse que no era cierto- en el impacto que esa información puede tener en los personajes considerados deudos del caballero, en las consecuencias argumentales que eso conlleva y en su exaltación como el mejor del mundo. Esta supuesta muerte se da en circunstancias semejantes, pero posee diferentes propósitos argumentales, así como distintas consecuencias.

La noticia de la muerte del caballero aparece en obras como Polindo (1526), Florambel de Lucea (1532) y Felixmarte de Hircania (1556), donde está relacionada con asuntos amorosos, por lo que la amiga del caballero es quien más sufre por dicha información: ya sea porque el protagonista le está haciendo un favor, como ocurre con Belisia, cuando cree que don Polindo ha muerto en la Cueva del Basilisco mientras intentaba rescatar a su padre (caps. 15-16); o ya porque siente que ella misma lo ha causado debido a su mandato de alejamiento, provocado por los celos, como ocurre a Groselinda con Florambel de Lucea (III, 36-39) y a Claribea con Felixmarte de Hircania (III, 5-6, 11). Un posible modelo remoto de este tópico sería El caballero de la carreta: luego de que Lancelot llega a Gorre a rescatar a la reina y va a buscar a Gavain, 
varios asuntos pendientes: la suerte de Policisne, la demanda que en su búsqueda emprenden los caballeros de Boecia, el encantamiento de la corte y el rapto del rey Arsandos, su tío. Y es que el efectismo y la plasmación de hechos sorprendentes y admirables son los valores imperantes del autor (Sales Dasí 2010: 2). Así, la inconclusa obra deja al lector conmovido, saturado de expresiones de dolor, con incertidumbre sobre el resultado, pero también con la expectativa de conocer la manera en que se resolverá todo 5 .

Sin duda, la noticia de la muerte del príncipe sirve para estremecer al rey y a toda su corte; pero también es utilizada por el autor para ir más allá: para dirigir las emociones tanto de los personajes como de los receptores de la obra. Pocas acciones narrativas ocurren en los numerosos capítulos que tratan sobre la reacción ante tales nuevas, porque el narrador está enfocado en indicar al lector la forma en que debe sentirse al respecto del caballero protagonista. En primer lugar, se busca hacer evidente el dolor que su pérdida causa en quienes lo conocen; esto contribuye a la exaltación del caballero por sus virtudes y su estado. Al mismo tiempo, en medio del dolor y el ensalzamiento - puesto que los personajes están casi seguros de la muerte, aunque no tengan el cadáver- surge la esperanza, particularmente en el plano del receptor, de que las cosas no pueden sino mejorar. Esta mezcla de sensaciones es propiciada por los recursos estilísticos y retóricos utilizados por el autor y que analizaremos a continuación.

En principio, el episodio está justificado por el odio que Caruça tiene al linaje real de Boecia; de allí que desee hacerle todo el daño posible y reconozca que,

llegan las noticias de su muerte. Ginebra, quien le ha dado una gélida bienvenida, se arrepiente y en su doloroso planto deja de comer y pone en riesgo su propia vida, hasta que vuelve a saber del caballero.

Pero hay otras muertes supuestas más allá del ámbito amoroso, como las de Rosicler (II, 28) en el primer libro de Espejo de Príncipes y caballeros (1555), o la de Don Clarís (I, 22), hermano del protagonista en Félix Magno (1549), relacionadas con el amor filial.

Hay otros episodios de noticias de la supuesta muerte del caballero que cumplen una función en el argumento muy similar a la del Policisne. En el Amadís de Gaula (1508), cuando Arcaláus el encantador va a la corte del rey Lisuarte a decir que mató al caballero (I, 18-20), su propósito es adjudicarse la fama del joven caballero y lastimar a Lisuarte (y, aunque en secreto, Oriana también sufre). Asimismo, en el Cristalián de España (1545), Drumelia la encantadora lleva las noticias de la muerte de don Cristalián y otros personajes importantes a la corte del emperador Aliandro de Persia, con la intención de hacer morir de dolor a la amiga del caballero, Penamundi (58-60). Estos personajes antagónicos, como Caruça, tienen el objetivo de hacer daño, lo que implica lastimar emocional y físicamente a alguien, debido a la triste — pero falsa- información.

5 En este sentido, el personaje de Caruça cobra una relevancia inusitada, pues al ser la portadora de las noticias pone en funcionamiento los propósitos del autor: «Aun estando equivocada (desconoce la pasión que Fidea siente hacia el protagonista), las referencias posteriores a sus maquinaciones y a su desmedida crueldad contribuyen a dotar la narración de unos augurios poco positivos. La funcionalidad actancial de Caruça repercute en la progresión de las expectativas que actúan sobre el lector a manera de anzuelo» (Sales Dasí 2009: 276). 
para conseguirlo, su mejor arma es la noticia de la muerte del heredero: «tales nuevas de aquel traidor del rey Minandro con que viva triste toda la vida él y la reina su muger. Que sabed que aquel era su hijo Policisne, del cual le haré saber que lo tenga por muerto de la más cruda muerte del mundo» (209). Por otro lado, el autor utiliza al personaje Tarín, hasta entonces compañero y escudero de Policisne y ahora preso de Caruça, para explicar las nefastas repercusiones de la noticia. Así, cuando le solicita que desista de su plan, no es un acto de ingenuidad sino un recurso autoral para dimensionarlo para el lector:

-Pues lo que yo querría — dixo Tarín-, es suplicaros que aquella carta de Policisne mi señor el rey Minandro ni la reina no la vean, porque su muerte causará, ni de su muerte que tan cercana tenía no le digáis.

-A Dios plega que ansí sea como dizes — dixo Caruça-, que esso me haze a mí estar tan leda: pensar que yo traigo en mi poder cosa con que su sobervia sea abaxada y mi ira vengada y satisfecha. Y vos no seáis osado de más esso me dezir, ni habléis palabra hasta que yo os lo mande, si no iros ha mal d'ello.

Tarín, que en su poder se vía con una gruessa cadena al pescueço, se calló bertiendo muchas lágrimas. (211)

Si bien Silva y de Toledo, siguiendo los preceptos del género, utiliza las aventuras admirables y los espacios maravillosos con «una voluntad para impresionar» (Sales Dasí 2010: 17), emplea la sutileza de los recursos estilísticos con esa misma intención. La actitud y situación de Tarín, la crueldad premeditada de Caruça y las consecuencias de la noticia promueven en el receptor cierta expectación, pero también lo llaman al estremecimiento constante.

En este sentido, la figura del recién nombrado caballero, maltrecho por su derrota ante Madaquer, será aprovechada para desplegar diversos recursos que dirijan las emociones del público. Por ejemplo, junto con la mención de los gestos y expresiones de dolor, el narrador destaca que hasta los enanos custodios se conmueven por él: «Y estas cosas y otras muchas Tarín de grande lástima dezía, dando grandes suspiros y bertiendo lágrimas en grande abundancia, tanto que a los enanos movía a piedad viendo las cosas que hazía» (210). Y, cuando van llegando a la ciudad de Tarina, los pensamientos del apesadumbrado testigo de la noticia también conducen al espectador:

Mas sentid lo que en coraçón sentiría a tal sazón, y dezía entre sí:

— $\mathrm{O}$, rey Minandro!, $¡ \mathrm{O}$, reina Grumedela! ¡Si supiéssedes las tristes nuevas que Tarín os trae y cómo a todos hallaría puestos en lutos y en continuos lloros! $¡ \mathrm{O}$, Cavalleros de Boecia, y cómo perdéis oy la honra y la prez de las armas! ¡O, Tarina, y cómo serás oy tornada triste y tenebrosa! ¡O, mi señor Grigendos y mi padre, cómo creo que la muerte terníades por mejor que tal cosa saber! (211) 
El narrador llama a la empatía del lector mediante expresiones que le indican la manera en que debería sentirse al ver su sufrimiento: «mas sentid». Rubio Pacho denomina a esta invitación llanto solidario: «pues no afecta únicamente a los involucrados, sino que implica incluso a los testigos, tanto personajes como lectores» (2012: 325). Además, a partir del discurso directo, desde el corazón del prisionero que participará las «tristes nuevas», se comparte la desesperación usando los apostrophos a sus conocidos y familiares, y adelantando lo que les espera a los personajes: luto, continuos lloros, tristeza y deseo de morir. Desde luego, no se olvida de lo que implica la pérdida: «la honra y la prez de las armas». Toda esta escena sirve para preparar el ánimo del lector pues es un anticipo de las consecuencias de la presencia de Caruça en la corte.

Ahora bien, Caruça no solo repite un rumor, ni tampoco asegura que Policisne está muerto. Lleva pruebas fehacientes de que el heredero de Boecia va camino de su perdición: ella misma es testigo de su deplorable estado, del cerco de sangre en que estaba, de su imposibilidad de luchar y de que va en manos de Fidea, la hija de Almandroga, la enemiga acérrima del linaje del rey. Por otro lado, la noticia está corroborada por Tarín, quien viste las rotas armas de su señor y contará las últimas hazañas del caballero. Y, como prueba final, presenta la carta que, con su puño y letra, escribió el herido príncipe ${ }^{6}$. Estos tres elementos funcionan en el plano narrativo de los personajes, para convencerlos; de allí que sus muestras de dolor sean tan contundentes y sinceras. En efecto, nada de lo que cuenta Caruça es mentira. Pero el lector podría albergar mayores esperanzas, pues tiene un mayor conocimiento que los personajes sobre Policisne: que la hija de Almandroga, Fidea, lo lleva porque está enamorada de él, no para hacerle daño; que tales heridas podrían ser curadas con facilidad y que tiene un libro dado por la maga Ardemula, el cual podría librarlo de cualquier encantamiento. Sin embargo, y a pesar de cualquier resquicio de confianza, el lector se verá envuelto en el llanto y el dolor, y será convidado a sufrir junto con los personajes:

Sabed que a la hora que Caruça estas tan dolorosas nuevas dixo fue el clamor y los llantos tan grandes en todo el palacio y de allí en la ciudad, que más día del juizio que otra cosa parecía, y querer decir en particular lo que cada uno hizo sería nunca

6 Esta carta tiene varias funciones: es de «creencia», de despedida y de testamento de Policisne. Primero advierte su situación adversa y otorga a Tarín el poder de contar todo lo que pasó; luego, lamenta el derramamiento de la sangre real - es decir, todo lo que implica la muerte del sucesor del reino- y da instrucciones sobre el león, que en realidad es su tío Ardineo, y sobre Flormira, su prima y heredera del trono. Asimismo, según su estamento caballeresco reparte sus pertenencias, hace el mortuarium (Español: 873) dejando a Tarín su armadura y espada. Finalmente, llama a no perder la esperanza en Dios, aunque la última frase es devastadora: «ponga en vos, mi señor, consuelo y en mí el remedio que tan alongado tengo» (215). 
acabar y dar enojo a los oyentes, mas que podrá cada uno juzgarlo, que no se puede dezir. (213)

En la reacción de la corte, el narrador otra vez apela directamente al espectador con la expresión «sabed...» y mediante la comparación con el día del juicio final — que recuerda al bíblico «allí será el lloro y el crujir de dientes» (Mateo, 8: 12) - , ayuda a exponer la magnitud del lamento. Además, retoma el tópico de lo indecible al aceptar su incapacidad para la descripción de todo, al tiempo que le solicita al lector compenetrarse con el pesar, al juzgarlo por sí mismo ${ }^{7}$. No queda fuera ninguna de las manifestaciones de dolor frente a la muerte que se expresaban a través del llanto, de la voz y de los gestos, comunes desde la Antigüedad, los cuales conformarían lo que Muñoz Fernández llama la «performance del duelo»:

Se reconocen expresamente los distintos lenguajes que convergen en relación de equivalencia con el llanto (el sonido y la palabra, el fluido corporal y las acciones de fuerte impronta gestual que incluyen acciones autolesivas). Tenemos pues identificadas las figuras del desorden y, con ellas, la performance del duelo. Su presencia conjunta, no solo su intensidad expresiva, denotaba a ojos de las gentes la magnitud del llanto, hacía grandes y memorables los duelos por los difuntos. (2009: 118)

Cada personaje presenta el duelo según su condición política y social. En primera instancia, en su papel de soberano, el rey guarda la calma, como era de esperarse (Cacho Blecua: 76), e incluso se mantiene escéptico a la información: «Dueña, querría que más estas tristes y amargas nuevas para mí declarássedes, por do seáis con razón más creída» (213). Pero en cuanto reconoce la letra de su hijo, el ánimo y apostura de su estado se desploman: «Oída la carta por el rey Minandro, por poco de su silla se cayera, quedando una pieça como muerto, si Urbín y Alderino del Lago no lo tuvieran. Y tornando en sí, se fue para Tarín, que en tierra estava, y, abraçándolo, començó a besar las armas y a él en el rostro» (214) ${ }^{8}$. Cuando Minandro trata de consolar y dar ánimo a la reina, se vuelve a destacar su discreción, a pesar de su enorme dolor. Esta escena resulta conmovedora debido a que el narrador utiliza dos estrategias: apelar a sus enemigos, quienes sentirían su dolor, y mencionar el intento de ocultar y detener las abundantes lágrimas:

Recordemos que, a decir de Viña Liste, «mediante el incremento del patetismo, un relato ficcional es susceptible de producir en sus receptores no solo la identificación con el dolor de los sufrientes, sino también, manejada con habilidad, una distensión emotiva, como válvula de escape en conflictos que al fin logran resolverse con felicidad» (221).

8 Minandro presenta un comportamiento un tanto desmesurado para un rey, pero no es el único. Rubio Pacho (327), en su análisis del Oliveros, destaca el llanto del rey de Castilla sin consideración a su estado, quien lamenta ostentosamente a su hijo, como si estuviera muerto. 
El rey la esforçava, aunque para sí avía menester el consuelo y esfuerço, que el suyo no bastava junto con gran discreción en aquella hora que del todo no pensassen los que lo vían qu'el seso perdiesse, según lo que hazía. Y dezía lástimas que aun a los que mal lo quisieran lastimara, encubriendo y deteniendo los arroyos de sus lágrimas que en grande abundancia vertía por sus fazes. (217)

Con respecto a la reina Grumedela, el impacto de la noticia de la muerte de Policisne será más ostentoso y significativo, particularmente si consideramos que a estas alturas del libro el caballero no tiene una amiga que llore por él; a lo que se añade todo lo que sufrió su madre hasta que logró concebirlo. Entonces aparece implícito un tópico pasionario usual desde la Edad Media, el Planctus Mariae:

El llanto por el hijo muerto generó arraigadas imágenes visuales y desarrollos narrativos ampliamente divulgados, acordes con el interés teológico y devocional que despertó entre las gentes. En esta tradición, el dolor de María fue comprendido como fuente de mérito y valor, como vía de ensalzamiento de la Madre que llegaba a igualarse al hijo. Se popularizó como una exposición extrema y extraordinaria al sufrimiento, porque extraordinario era el proceso en el que este sufrimiento se enmarcaba: la obra de la redención humana. (Muñoz Fernández 2006: 241)

La reacción inicial de la madre del caballero fue perder el conocimiento por casi seis horas, a causa del gran dolor. Cuando volvió en sí, sus actitudes son el sobresalto y el gemido; el narrador añade que el corazón se le saldría por los saltos y temblores (217). Silva aprovecharía la imagen de María y su dolor para equipararla con Grumedela y así mantener sobrecogido al lector. El prolongado desmayo de la reina recuerda al de María durante la crucifixión de su hijo ${ }^{9}$. Pues, sin duda, su público mantendría presentes estas referencias gracias a los numerosos autos que conmemoraban la pasión de Cristo, que tan populares fueron a lo largo del siglo XVI, tanto en libros como en representaciones y pliegos sueltos (Coduras Bruna: 119). A estas poderosas imágenes, hay que añadir el planto o discurso de lamento que realiza la madre del caballero. La reina empieza con la lamentatio, en donde incluye algunos tópicos funerarios (Hernández Pérez 2001), como el de la mors immatura, utilizando la metáfora de la flor del campo, y la laudatio funebris, alabando sus virtudes principales: belleza, bondad y oficio caballeresco. También, la reina recurre al taedium vitae, pues sin su hijo y heredero no le encuentra sentido a la vida ${ }^{10}$. Todo lo cual tiene la función de conmover al lector o, por lo menos,

\footnotetext{
9 Por ejemplo, en la Passión Trobada de Diego de San Pedro: «la fuerça le falleció / y tan grand dolor sintió / que cayó muerta en el suelo / y después que ya tornó» (Cita en Coduras Bruna: 119).

10 «Mas la reina, torciendo sus manos y hiriendo su rostro con ellas, no escuchava ni tenía sentido a las razones del rey, que bien pensó que aquella esperança que le dava era incierta y sin camino para creerse. Y con grandes y dolorosos sospiros dezía:

${ }_{i \mathrm{O}}$, mi hijo Policisne, fin amargo de vuestros padres! ¿Y quién fue ni quién pudo dar a vuestra
} 
hacerlo partícipe de la pérdida enorme que la muerte del caballero representa para todos los personajes. Por otro lado, la reina pasa casi dos meses en ayuno y, debido al llanto, queda ciega y postrada en cama: «que la reina eran tantas sus lágrimas que de día y de noche derramava que la vista avía perdido y, con esto, estava siempre en su lecho, que nunca d'él se levantava» (247).

$\mathrm{Y}$ en ese sentido, el narrador se explaya en el sentimiento de la corte a partir de las reacciones de las mujeres, los ciudadanos de Tarina así como de los caballeros. El palacio y la ciudad fueron cubiertos de luto el mismo día de la triste noticia mientras que sus habitantes compartían el dolor. Llama la atención la escena de las madres lastimando a los niños ${ }^{11}$ y la expresión caballeresca de romper los escudos (Español: 873) ${ }^{12}$. Todo es sufrimiento externo: llantos, gritos, paños negros. Esta demostración social de duelo es importante, no tanto para la historia ni su avance narrativo, sino por la impresión que puede causar en el espectador:

El palacio fue ansí mesmo desapostado de sus ricos paños y guarnimiento y toldado de paños negros; $y$ tan gran mudança se hizo en todo y todos lo hizieron que

hermosura la muerte? ¿Quién fue tan cruel que en viéndoos no perdiesse su mal talante, ni quién pudo engañar a toda la bondad del mundo para d'él sacar el resplandeciente luzero de la caballería? ¿A dó llegarán, flor del campo, que ansí fuestes vos, que en saliendo con su hermosura en la mañana al mediodía es seca, los vuestros hazañosos hechos, que de ayer armado por vuestro lastimado padre cavallero hizistes cosas tan estrañas que la memoria d'ellas hará buenos a los que la bondad querrán seguir? Pues no me conviene vivir, mas lo que durar pudiere hazer por vos tal vida que más gentes no vean que vivo sin vos, pues sois pérdida que ninguna iguala, yo moraré de aquí adelante entre las fieras sierpes y leones de las montañas, porque no ternán razón ni consuelo para esta triste y lastimada reina que tan pocas horas meresció ser vuestra madre» (217).

11 En este sentido, el llanto y los gestos de las mujeres son muy relevantes. Muñoz Fernández considera estas actitudes como códigos simbólicos que llaman a la reacción: «La compasión se desenvuelve también en el marco de las relaciones sociales y contiene un doble principio de tipo reactivo y vincular. Las mujeres fueron las más activas y eficaces canalizadoras de esa fuerza» (2006: 260); de allí que «al dejar en suspenso la responsabilidad del cuidado del propio cuerpo, las inclinaciones del placer personal y las reglas del decoro social, las madres, esposas, hijas o parientas del difunto contribuyeron poderosamente con sus acciones a crear ese radical estado de excepción que se abría con la muerte de alguien y se ritualizaba con el duelo» (2009: 137).

12 El duelo de los caballeros incluye llanto y otras señales externas de luto, como el del conde Limercio: «Todos venían armados de unas muy fuertes armas y los escudos negros sin ninguna divisa en ellos, vestían sobreseñales de luto. Detrás de ellos venía uno, desarmada la cabeça, que señor de los otros parescía y tres escuderos tras él; y él venía limpiando con un paño los ojos, que en su semblante mostrava llevar gran duelo y tristeza» (233). Pero, como parte de su oficio, además, se destaca el deseo de venganza por parte de los compañeros de armas de Policisne: Tarín, el Caballero del Ave, Fimeo y el infante Plumedoro, entre otros. Incluso uno de sus adversarios, Orminel, desea emprender la búsqueda: «De aquí juro, por la fe que devo a Dios, que pues era obligado si vivo fuera a ir a doquiera que supiesse que él estava y a buscarle, de lo hazer agora para vengar su muerte y tener compañía a los que en esta demanda anduvieren. Pues yo le buscava para hazer batalla con él, aora será para hazerla con quien fue causa de su muerte aunque a mi cueste la vida» (242). 
no avía hombre que aquella noble corte un día antes huviera visto que el coraçón no quebrantara de ver tan al rebés sus plazeres y su honra tan abaxada, que no avía muger ni hombre en toda Tarina que de duelo no fuessen cubiertos. Las ventanas de las casas fueron tapadas y teñidas las paredes de negro. A los niños sus madres no les davan de mamar las vezes que antes solían y a los mayores, que aún sentimiento no avían de sentir, los herían, porque juntamente con ellos llorassen su pérdida. Tres meses duraron los lloros en Tarina y en toda Boecia, que otra cosa de día y ni de noche se ohía a toda hora sino clamores y suspiros. El real palacio fue todo por de fuera con los tejados cubierto de paños negros, y ante él aquellos preciados cavalleros quebraron sus escudos y tenían sus armas, jurando perder la vida en esta demanda. Quién vos podrá dezir en particular lo que cada uno d'ellos hazía y dezía, que sería nunca acabar. $(218)^{13}$

Por si esto fuera poco, la manifestación externa del dolor se hace más evidente en las figuras conmemorativas de las últimas hazañas del caballero, narradas por Tarín, que el rey manda a construir. Allí se crea un espacio para el dolor público: todos pueden acudir a la Calle de las Aventuras a «ver» y a llorar a su señor ${ }^{14}$. Lo cual aumenta el patetismo, con la imagen de las doncellas arrancándose el cabello por el dolor ${ }^{15}$ :

13 El luto del castillo también remite a la pasión de Cristo, particularmente al triduo pascual, o triduum sacrum, así como los tres meses de duelo parecen remitir a números simbólicos cristianos. En este sentido, aunque la caracterización del caballero - y el enfoque general de la obra - no está inclinada a la ideología cristiana ni a la cruzada, Silva y de Toledo parece ofrecer, a partir estas manifestaciones de dolor, una equiparación velada del caballero con el propio Cristo.

14 Pareciera que para narrar estos episodios el autor - ni sus posibles lectores - no tiene en cuenta la Pragmática del 20 de marzo de 1565, firmada por Felipe II, donde se recuerda la prohibición de estas manifestaciones: «Otrossí, en quanto toca a los lloros, llantos y otros sentimientos que por los dichos difuntos se acostumbran facer, se guarde lo que está ordenando por las leyes de nuestros reynos, so las penas en ellas contenidas» (cita en Muñoz Fernández 2009: 111). Como tampoco se consideró en otros libros de caballerías como el Lisuarte de Grecia, donde se narró lo que se convertiría en la incómoda muerte del rey Amadís de Gaula (Coduras Bruna 2011).

15 Los gestos, por su plasticidad, aportan mayor intensidad emocional; lo cual contribuye al patetismo buscado por el autor: «La crudeza de las expresiones deja poco lugar a la duda; vinculado al duelo y al lamento por los difuntos, a los momentos de mayor alteración y conmoción, se sitúa un aparato gestual bien conocido que conlleva acciones autolesivas como mesarse los cabellos y las barbas, o lastimarse el rostro y las manos. Exhibirse sin tocado, "descabelladas", arrojar las tocas al suelo o rasgarse las vestiduras, fueron modalidades específicamente femeninas que se sumaban a las maneras de llorar con las manos y con el cuerpo. Alineadas con los lloros, gemidos, gritos y plantos, todas las potencialidades expresivas del cuerpo humano quedaban activadas con estas prácticas aportando una intensidad, un dramatismo y una plasticidad sin par a las "representaciones" del planto» (Muñoz Fernández 2009: 132). También hay que recordar que a los gestos "se les entiende como un modo visible de revelar el ser interior, de ahí que en la literatura se use la gesticulación como un mecanismo de caracterización, puesto que por sí misma muestra el alma de un personaje» (Walde: 111).

Edad de Oro, XXXIV (2015), pp. 115-130, ISSN: 0212-0429 
Y fueron puestas aquellas figuras de muy preciados mármoles y piedras de gran valor en una calle muy ancha y muy larga por el medio de ella, que la más principal de la ciudad era, la cual de aí adelante se llamó la Calle de las Aventuras. Y eran tantos los clamores de las gentes desque esto se hizo que los más días se llegavan a hazer grandes duelos en cada passo y historia de ellas, y dexar las donzellas los cabellos que mesavan entre aquellas imágines y figuras, resgando sus rostros y vestiduras con sus manos sin ninguna piedad. (218)

A todas estas expresiones de tristeza, el autor añade un círculo doloroso con la llegada del enano Overil, quien fuera uno de los compañeros cercanos de Policisne. Su presencia en la corte implicaría un nuevo dolor para los reyes; por eso, los consejeros piden a Overil que no se deje ver. Este evento contribuye a que el lector se conduela de la situación. Se trata de una pena tan intensa que, en ese momento, cualquier noticia o elemento que recuerde a Policisne provocaría mayor sufrimiento. Así, todos padecen. El enano está triste no solo por su propia pérdida; sabe que él incrementa la pena de los otros. Esto es claro con las primas del caballero $^{16}$ :

Pineda que lo oyó, se asomó por ver quién fuesse; y tomole tanta alteración de ver a Overil, aunque bien sabía que allí estava, por lo que Flormira avía de sentir que por pocas se cayera del otro cabo. Y tornando en sí, le dixo:

- ¡Ay, amigo Overil, y cuán triste me haze la vuestra vista, que las fuerças me han faltado y el aliento en saber cuánto Policisne os amava y de lo que mi señora Flormira sentirá en veros!

Y como esto dixo, que Overil la conoció, començó a llorar y a dar con la cabeça en las piedras sin le poder responder una pieça. Flormira que algo sintió, que vistiéndose estava, salió muy alterada diziendo:

- Señora cormanda, ¿con quién habláis?

Y como esto dixo se asomó y vio a Overil abaxo, y dio una voz diziendo:

- ¿Este es Overil? ¡Ay, amigo, y cuánto tu vista mi cuita acrescienta!

Esto dezía Flormira con tantas lágrimas que Overil se quisiera entonces matar con pesar, diziendo:

16 El dolor de las primas del caballero es relevante, porque en términos pasionarios ellas se asemejarían a las mujeres cercanas a Cristo que lloran su muerte y acompañan a María en el dolor. Así, Flormira sufre por el caballero como Magdalena por su señor, según se ve en el Cancionero de Gómez del Ferrol: «La Magdalena que allegava; / e tan grandes vocez daba, / como loca de las locas, / ¡la su cara e las sus tocas/ sin piadad cómo rasgava!» (Cita en Muñoz Fernández 2006: 243).

Pero tampoco puede olvidarse que estas reacciones femeninas sustituyen a las que manifestaría la amiga del caballero al conocer su muerte - como las de Oriana (Walde 2009) - y que son comunes en este tópico caballeresco; sin embargo, Clarinda, la que sería enamorada del caballero, es apenas un personaje de referencia. 
-Señora, por la fe que a Dios devéis, que hagáis de guisa que la reina mi señora no os oiga, que gran mal sería. (226-227)

Como puede verse, ningún personaje deja de manifestar su pesar, siempre según su posición social, género o condición (Cacho Blecua: 74). Además de contribuir con la intención de conmover al lector, la exposición tan detallada de este dolor sirve para hacer patentes las funciones bélica y política de Policisne como príncipe heredero de Boecia ${ }^{17}$. En este punto hay que recordar que el duelo podía ser un cauce de expresión y sufrimiento, pero particularmente el público y colectivo «se convertía de hecho en una obligación social que servía para manifestar públicamente solidaridades de sangre o de grupo, e incluso fidelidad a un poderoso» (Martínez Gil: 200), lo cual, en nuestra obra, estaría ligado a la exaltación del caballero ${ }^{18}$. En todos los discursos de lamento resulta evidente que esa es la función que más interesa al autor. De allí que haya algunas manifestaciones particulares de otros caballeros que lo exaltan. Nuevamente esta misión está encomendada a Tarín, testigo — junto con el público- de las últimas acciones de Policisne:

Y sentándose el rey y haziendo llegar a Tarín cabe sí, que la cuita y desmayo que tenía del suelo no le avía dexado alçar, dixo en alta voz:

- Lastimado rey, pues esto es cosa para que en ti y en todos los coraçones haga mayor la pérdida de lo que es, si Dios ha permitido que muerto sea el más esforçado cavallero y el mejor de todo el mundo, dexando huérfana y sin favor la orden militar, ansí quiero que sepáis sus hazañosos hechos. (215)

Tarín desea contar lo que pasó con Policisne para alimentar su fama, al dar a conocer sus postreras aventuras. Hay que observar que el dolor lo tenía postrado

17 La muerte de Policisne es relevante para todos, pero especialmente para los reyes pues era su heredero deseado. Al verse sin él, sus esfuerzos vitales, y sobre todo estamentales, pierden sentido. De allí que su primer impulso haya sido irse a un monasterio, fuera del mundo. Justamente a aquel donde surgió la promesa del nacimiento de Policisne: «Que sabed que a la hora que el rey y la reina aquesto supieron de Caruça, se quisieron retraer en un hermoso monasterio que avían hecho en la Cueva del Ximio, allí do el santo Frontonio hazía vida, como al principio de esta historia se ha contado. Mas ninguno uvo que por su parte esto no lo estorbasse, porque en sus días no querían conocer otro señor, pues ninguno tal en el mundo como él se hallaría» (246).

18 Para los autores de ficción caballeresca no resulta ocioso detenerse en la muerte de sus caballeros, ya sea que ocurra por diversas circunstancias como la de Tristán (Contreras Marín 2009) o Tirant (Beltrán Llavador 1997); ya sea la «buena muerte» por vejez como la de Palmerín (Bueno Serrano 2008) o la de Amadís, en el Lisuarte de Grecia (Coduras Bruna 2011). En cualquier caso, todas ellas contribuyen a redondear la caracterización del personaje protagonista y tienen el objetivo primordial de «publicar la excelencia y superioridad del héroe» (Bueno Serrano: 32). El caso del Policisne tiene la peculiaridad de que se exalta al caballero a través del duelo cuando su fallecimiento no es un hecho seguro.

Edad de Oro, XXXIV (2015), pp. 115-130, ISSN: 0212-0429 
en el piso y que las hazañas del héroe fueron oídas con expectación y llanto. Otra vez, el narrador emplea el tópico de lo indecible: «Mas las lágrimas y solloços del rey Minandro y de todos eran tantas a esta sazón, oyendo estas nuevas, que no ay quien lo cuente, que más de tres horas Tarín tardó en las contar» (216). La escena muestra la justificación misma del dolor: el caballero merece ser llorado porque su ausencia implica una pérdida para la comunidad guerrera completa.

Así, los deudos del caballero sufren porque se ha dañado a la orden de caballería. Es el caso del lamento de Overil: $\ll_{i} \mathrm{O}$, ventura, cómo diste tan presto fin aquel que en bondad de armas y virtudes era el primero que nació de cuantos nascerán!» (225). Como Grumedela, Flormira, la prima del príncipe, lamenta su muerte en la plenitud de la hermosura y juventud, con el tópico funerario mors immatura; pero haciendo énfasis en el truncamiento de una carrera bélica promisoria:

¡Ay, ventura, y cómo te mostraste tan contraria a todos los que venturosos hiziste en darnos a conocer aquel en quien todo bien del mundo y bondad de armas está encerrada! ¡ $\mathrm{O}$, muerte, si vengaras primero tu saña en los que dexas tan lastimados que no en el que tan gran presto cortaste sin temor de sus fuertes braços ni piedad de su hermosura y floresciente edad! (227)

Y para que no quede duda, otra mujer, pero con oficio caballeresco, la reina Galercia, sentirá en esos mismos términos la pérdida: «iO, esfuerço!, que es más de tener en vos por ser vuestra edad tan en flor; que por ello se saca que si la fortuna tan contraria a vos a todos no nos fuera, desque a edad cumplida llegárades espantaran vuestros hechos» (234).

Ante tal torrente de lamento y dolor resulta evidente que se trata de una estrategia discursiva del autor para mostrar la valía de su caballero. Desde el inicio, la estructura de la obra parecía plantear una extensión considerable dado el número de personajes y aventuras abiertas (por ejemplo, la aventura de la cierva encantada, a cargo del infante Panfirio); de allí la retardada e incluso difusa presencia del caballero. Policisne es el deseado heredero del rey Minando de Boecia pero su protagonismo está diluido por las múltiples aventuras de caballeros como Fimeo, Lunedos o Panfirio. Con todo, en sus propias aventuras destaca por sus capacidades guerreras, incluso en su encuentro con Rimacio y sus caballeros sobresale, a pesar de la traición y las graves heridas que lleva cuando sube a la barca de Fidea. No queda más que sospechar que Silva y de Toledo pudo haber reconocido esta dilución del caballero y, a fin de mantener la atención en sus hazañas y en el ansiado reconocimiento de su valor, recurre a su exaltación con una suerte de peculiar panegírico; peculiar, puesto que el caballero no está muerto.

Y en este sentido, se evidencia la forma en que el autor controla las emociones del público, no solo al provocarle a lástima por los deudos del caballero y 
al reconocer la valía del protagonista, sino también al hacerlo esperar la prometida segunda parte, donde todo se aclararía. Sales Dasí asegura que «el narrador manipula el orden lineal de los acontecimientos con el objetivo de crear una máxima tensión climática e infundir en el lector un gran interés hacia la hipotética continuación de la historia» (2010: 25). Cuando el narrador explica las apariciones proféticas de la sabia Ardemula, protectora del clan de Policisne, con respecto a la prisión del rey Arsandos, adelanta lo que pasará en la continuación del libro:

Con todo lo que al rey Minando y a Policisne su hijo amava, no púdose escusar por alcançar que Dios era servido que ansí se cumpliesse su voluntad, que puesto que ella sabía no ser Policisne muerto y que con hazerlo ella saber al rey y a la reina su madre estorbara al parecer sus llantos y los que sus vasallos hazían, como ya se os dixo, y los grandes desassossiegos que adelante en la segunda parte se dirán a esta causa se siguieron, no era ella poderosa de estorbarlo, sabiendo que la voluntad divina era que ansí passasse. (244)

Ardemula sabe que Policisne está vivo pero por voluntad divina - o, mejor: autoral- no puede advertirlo a sus deudos. Es decir, es necesario que los personajes sufran por la muerte de Policisne; porque, entonces, el autor ofrecería un respiro al lector: todo el duelo ayuda a preparar su ánimo para el segundo libro, donde todos los hilos que ha dejado abiertos se complicarán pero se cerrarán.

Una segunda parte del libro sería lo esperable. La división en «libros» o «partes» de las biografías o sagas familiares de un caballero famoso es bastante común en el género, ya que los autores buscan - y el público espera- la superación de las aventuras iniciales del protagonista. Así, mediante algunos elementos, problemas o personajes incluidos en la primera obra, se propicia la necesidad de una continuación (Eisenberg 1982: 127), en la que entrarían nuevos prodigios, conflictos más profundos o, simplemente, nuevos escenarios y personajes.

En el caso del Policisne, la primera parte parece no llegar a la culminación inicial del caballero, sino que termina abruptamente con dolor y llanto por su muerte (Sales Dasí 2009: 281), dejando las aventuras más importantes sin resolución. Sin embargo, en cada laudatio funebris de los deudos del caballero supuestamente muerto, se destaca la exaltación a su primer ciclo de aventuras logradas, aunque hayan sido tardías y quedaran dispersas entre las aventuras y prodigios maravillosos de otros caballeros. A pesar de eso, en la narración reiterada del lamento esas incipientes aventuras son engrandecidas. El interés por el segundo libro, entonces, se agudiza, porque el autor ha sabido ofrecer como promesas los cabos sueltos de su historia, principalmente al dejar inconclusa la más importante en términos amorosos: el desencantamiento de Clarinda. No queda duda, pues, «que era capaz de dotar su fábula de un elogioso suspense que despertaba la necesidad de seguir adelante con las expectativas planteadas» (Sales Dasí 2009: 270). 
Si a lo largo de la obra las hazañas de Policisne se vieron un tanto diluidas por su escasa presencia, aquellas que realizó han sido recordadas en medio de duelo, incluso con monumentos de mármol que las representan en la Calle de las Aventuras. Con el planto y las expresiones de dolor se le caracteriza y exalta como el mejor caballero del mundo. Es decir, si la obra careció de contundencia en la narración de las aventuras del caballero, mediante el episodio causado por las nuevas de su muerte se le va a magnificar y a dimensionar como el verdadero y único protagonista de la novela.

Finalmente, la segunda parte nunca apareció. Entre el aparente declive de esta literatura - propiciado por diversas circunstancias como los costos de impresión, el desgaste del género, las críticas de sus detractores- y la llegada del hidalgo manchego, el gran final de las caballerías, por lo menos de las impresas, llegó antes que la promesa de Silva. De forma tal que los lectores -incluso los actuales- han de llorar no solo por Policisne de Boecia sino por el caballero andante desaparecido, herido de muerte, en manos de sus enemigos.

Recibido: $22 / 05 / 2015$

Aceptado: 27/07/2015

\section{OBRAS CITADAS}

Beltrán Llavador, Rafael (1997). «La muerte del Tirant: elementos para una autopsia» En Jean Marie Barbera (ed.), Actes del Col-loqui Internacional Tirant Lo Blanch: L'arbor de la novel-la moderna europea: Ais de Provença, 21-22 d'octubre de 1994. Barcelona: Publicacions de l'Abadia de Montserrat, pp. 75-93.

Bernal, Beatriz (2014). Cristalián de España [Valladolid, 1545]. Edición de Jodi Growitz. Newark: Juan de la Cuesta.

Bueno Serrano, Ana (2008). «La muerte de Palmerín de Olivia (Primaleón, II, CCXII, 535-537) interpretada con ayuda de los motivos folclóricos», Memorabilia, 11, pp. 31-46.

Cacho Blecua, Juan Manuel (2009). «Introducción a los gestos afectivos y corteses en el Amadis de Gaula». En Aurelio González y Axayácatl Campos García-Rojas (eds.), Amadís y sus libros: 500 años, México: El Colegio de México, pp. 55-93.

CAMPOS García-Rojas, Axayácatl (2009). «"Después que por muerta de todos era juzgada”: Muerte aparente y anhelo de inmortalidad en los libros de caballerías hispánicos»». En Aurelio González y Axayácatl Campos García-Rojas (eds.), Amadís y sus libros: 500 años, México: El Colegio de México, pp. 199-223.

Corduras Bruna, María (2011). «La presencia de las sagradas escrituras, la devoción pasionaria y los ritos de pasaje en la muerte de Amadís en el Lisuarte de Grecia de Juan Díaz (1526)», Tirant, 14, pp. 111-128. 
Contreras Martín, Antonio (2010). «Muerte y entierro de Tristán en el Tristán de Leonís (Valladolid, 1501)». En José Manuel Fradejas Rueda, Deborah Anne Dietrick, María Jesús Díez Garretas y Demetrio Martín Sanz (eds.), Actas del XIII Congreso Internacional de la Asociación Hispánica de Literatura Medieval (Valladolid, 15-19 de septiembre de 2009): In Memoriam Alan Deyermond. Valladolid: Universidad de Valladolid, pp. 553-562.

Cuesta Torre, Luzdivina (1999). «La muerte aparente: un episodio en el Libro de Apolonio», Livium, 13, pp. 9-21.

Félix Magno (I-II) [Sevilla, 1549] (2001). Edición de Claudia Demattè. Alcalá de Henares: Centro de Estudios Cervantinos.

EISENBERG, Daniel, (1982). Romances of Chivalry in the Spanish Golden Age. Newark: Juan de la Cuesta.

Enciso Zárate, Francisco de (2009). Florambel de Lucea. Primera parte (libros I-III) [Valladolid, 1532]. Edición de María del Rosario Aguilar Perdomo. Alcalá de Henares: Centro de Estudios Cervantinos.

ESPAÑOL, Francesca (2007). «El "córrer les armes”. Un aparte caballeresco en las exequias medievales hispanas», Anuario de Estudios Medievales, 37: 1, pp. 867-905.

Hernández PÉREZ, Ricardo (2001). Poesía latina sepulcral de la Hispania Romana: estudio de los tópicos y sus formulaciones. Valencia: Universitat de València.

MarTínez GiL, Fernando (2000). Muerte y sociedad en la España de los Austrias. Cuenca: Ediciones de la Universidad Castilla-La Mancha.

Muñoz FernándeZ, Ángela (2006). «Planctus Mariae. Mujeres, lágrimas y agencia cultural», en Arenal, 13: 2, pp. 237-261.

(2009). «Llanto, palabras y gestos. La muerte y el duelo en el mundo medieval hispánico (morfología ritual, agencias culturales y controversias», Cuadernos de Historia de España, 83, pp. 107-139.

OrtegA, Melchor de (1998). Felixmarte de Hircania [Valladolid, 1556]. Edición de María del Rosario Aguilar Perdomo. Alcalá de Henares: Centro de Estudios Cervantinos.

OrtúÑez de Calahorra, Diego (1975). Espejo de Príncipes y Cavalleros [El Cavallero del Febo]. Edición de Daniel Eisenberg. Madrid: Espasa-Calpe.

Polindo [Toledo, 1526] (2003). Edición de Manuel Calderón Calderón. Alcalá de Henares: Centro de Estudios Cervantinos.

Rubio Pacheco, Carlos (2012). «"Bien tuviera el coraçón duro si con ella no llorara”: la retórica del llanto en el Oliveros de Castilla», en Aviva Garribba (ed.), Rumbos del hispanismo en el umbral del Cincuentenario de la AIH. Vol. II: Medieval. Roma: Bagatto Libri, pp. 322-327.

Russell, Peter (1982). «The Last of the Spanish Chivalric Romances: Don Policisne de Boecia». En R. B. Tate (ed.), Essays on Narrative Fiction in the Iberian Peninsula in Honour of Frank Pierce. Oxford: Dolphin, pp. 141-152.

Sales Dasí, Emilio José (2008). «Introducción», en Policisne de Boecia [Valladolid, 1602]. Alcalá de Henares: Centro de Estudios Cervantinos, pp. IX-XXIX.

(2009). «"La más cruda y engañosa muger del mundo”: un personaje singular del Policisne de Boecia». En Tom Lathrop (ed.), Studies in Spanish Literature in Honor of Daniel Eisenberg. Newark: Juan de la Cuesta, pp. 267-293. 
Sales Dasí, Emilio José (2010). «El Policisne de Boecia y la tradición amadisiana un siglo después», Destiempos.com, 27: 2, pp. 2-33.

Silva y De Toledo, Juan de (2008). Policisne de Boecia [Valladolid, 1602]. Edición de Emilio José Sales Dasí. Alcalá de Henares: Centro de Estudios Cervantinos.

ViÑa LisTE, José María (1999). «Variaciones sobre el motivo o tópico del llanto en el Libro del caballero Zifar», La Corónica, 27: 3, pp. 207-226.

WALDE, Lillian Von der (2009). «Representación retórica de la emoción». En Aurelio González y Axayácatl Campos García-Rojas (eds.), Amadís y sus libros: 500 años, México: El Colegio de México, pp. 95-108.

La noticia de la muerte de Policisne de Boecia: expresiones de dolor en un libro inconcluso

Resumen: Este artículo analiza las expresiones de dolor surgidas por la noticia de la supuesta muerte del caballero protagonista en el Policisne de Boecia (Valladolid, 1602) a fin de identificar los mecanismos estilísticos con los que el autor, Juan de Silva y de Toledo, busca conmover al lector, exaltar las hazañas del caballero y generar expectativas sobre la segunda parte del libro.

Palabras clave: duelo, planto, llanto, emoción, secuela, caballerías.

The news about Policisne de Boecia's death: pain expressions in an unfinished romance

ABSTRACT: This article analyzes the pain expressions produced by the news of the knight's alleged death in Policisne de Boecia (Valladolid 1602), in an attempt to identify the stylistic mechanisms by which the author, Juan de Silva y de Toledo, aims to affect the reader's emotions, extol the knight's exploits and raise expectations about the inexistent book's sequel.

KEYWORDS: Grief, mourning, weeping, suspence, continuation, chivalry. 
TERESA DE JESÚS (1515-1582)

Guillermo Serés (Universidad Autónoma de Barcelona)

La imaginación de Santa Teresa: virtudes y desatinos de «la loca de la casa»....... 11

Ana Garriga EsPino (Universidad Autónoma de Madrid)

El desafío editorial de las cartas de Teresa de Jesús.

LeCTURAS REPUBLICANAS DEL QUIJOTE

RAQUEL ArIas (Universidad Autónoma de Madrid)

León Felipe alista a don Quijote en el bando republicano. 57

MANUEl LóPez ForJas (Universidad Autónoma de Madrid)

El Quijote y la realidad viva de las Españas: la visión histórica

de Pedro Bosch-Gimpera.

CArmen Madorrán Ayerra (Universidad Autónoma de Madrid)

El Quijote como utopía necesaria: la mirada de Adolfo Sánchez Vázquez 85

\section{OTROS TEMAS}

SònIA BoADAS (Universitat Autònoma de Barcelona)

Libros y librerías: la recepción de Commynes en España 101

Lucila Lobato Osorio (Universidad Nacional Autónoma de México)

La noticia de la muerte de Policisne de Boecia: expresiones de dolor en un libro inconcluso.

María Gutiérrez Padilla (Universidad Nacional Autónoma de México)

La escenografía en el teatro caballeresco 131

ADRIÁn FERnÁNDEZ (Université de Fribourg)

Dos entremeses «auditivos» y sus niveles: hacia un metateatro visual. 145

David González de la Higuera Garrido (Universidad Complutense de Madrid) La visión premonitoria de Alonso en El caballero de Olmedo:

otra recuperación de lo popular

Esther Fernández LóPEz (UNED)

Perseo en la comedia tardobarroca: Ignacio Ferrera y Pasqual 169

Manuel Piqueras Flores (Universidad Autónoma de Madrid)

De La hija de Celestina $a$ La ingeniosa Elena: estructura narrativa, género literario e interpolación 
Dagoberto CÁceres Agullar (Western University Canada)

Realismo incesante: desde Celestina hacia su recepción 201

TeXTOS INÉDITOS

Davinia Rodríguez Ortega (Universidad Pública de Navarra)

Auto sacramental del Juego del Hombre, de Luis Mejía de la Cerda:

edición crítica 


\section{EDAD DE ORO}

Revista de Filología Hispánica XXXIV

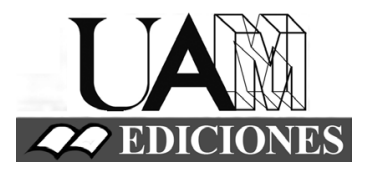




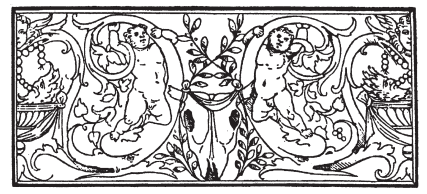

\section{Edad de Oro. Revista de Filología Hispánica}

ISSN: 0212-0429

Dirección:

Teodosio Fernández

Secretaría y edición:

José Ramón Trujillo

Comité científico internacional:

Carlos Alvar (Univ. de Ginebra)

Ignacio Arellano (Univ. de Navarra)

Javier Blasco (Univ. de Valladolid)

Alberto Blecua (UAB)

Jean Canavaggio (Univ. de París X)

Laura Dolfi (Univ. de Turín)

Aurora Egido (Univ. de Zaragoza)

Víctor García de la Concha (RAE)

Luciano García Lorenzo (CSIC)

Joaquín González Cuenca (Univ. de Castilla-

La Mancha)

Agustín de La Granja (Univ. de Granada)

Begoña López Bueno (Univ. de Sevilla)

Michel Moner (Univ. de Toulouse III)

Joan Oleza (Univ. de Valencia)

Alfonso Rey (Univ. de Santiago)

Lina Rodríguez Cacho (Univ. de Salamanca)

Leonardo Romero Tobar (Univ. de Zaragoza)

Aldo Ruffinatto (Univ. de Turín)

Lía Schwartz (City University of New York)
Redacción y admisión de originales:

Teodosio Fernández

Edad de Oro

Departamento de Filología Española

Universidad Autónoma de Madrid

28049 Madrid (España)

Tfno.: +0034914974090

correo: teodosio.fernandez@uam.es

Distribución, suscripción y venta:

Servicio de Publicaciones de la UAM

Universidad Autónoma de Madrid

28049 Madrid (España)

Intercambio de publicaciones:

Biblioteca de la Facultad de Filosofía y

Letras (UAM)

Universidad Autónoma de Madrid

28049 Madrid (España)

Han colaborado en este volumen:

Departamento de Filología Española (UAM)

Facultad de Filosofia y Letras (UAM)

Edad de Oro se recoge, entre otras, en las siguientes bases de datos: SCOPUS, MLA Database, HLAS, Latindex, PIO-Periodical Content Index, ISOC, Dialnet, MIAR, ERIH, DICE, Sumaris CBUC, Ulrich's. Se encuentra evaluada en CIRC: A; INRECH; MIAR difusión ICDS live: 9.977; SCImago Journal \& Country Rank: H Index 2, SJR 0,101, Q4; RESH índice de impacto: 0.041; ERIH: A INT1; Carhus Plus+ 2014: C. 